\title{
The Dispersal of the Ingrian Finns
}

Before the 1917 Revolution, about one hundred and thirty thousand people of Finnish origin lived on Russian territory on the south shore of the Gulf of Finland-from the Narva River in the west to the Neva River in the east, and in the region north of St. Petersburg. Their numbers remained fairly constant during the 1920s and early 1930s, but, after the Second World War, a great decrease was evident in the total Finnish population of the region, with only about twentyfour thousand recorded in the 1970 Soviet census. This drop in population is attributable not only to the ravages of the war but also to movements of people, including deportations that took place during the 1930s and 1940s.

The region inhabited by this Finnish population is known as "Ingermanland" to the Swedes and Germans, "Ingria" to the Russians, "Inkeri" or "Inkerinmaa" to the Finns, and "Ingerimaa" to the Estonians. The original Finnish name for the region was probably "Ingerinmaa." 1 The Finns of the region are generally called "Ingermanland Finns" or "Ingrian Finns," although in the mid-1920s they received the official Soviet title of "Leningrad Finns" (Leningradskie finny). The Finns use the names "inkeriläiset" or "Inkerin suomalaiset" (Ingrian Finns). The entire territory settled by the Ingrian Finns is now contained within the boundaries of Leningrad oblast. ${ }^{2}$

The lands of the Ingrian Finns consist of a swampy coastal plain along the Gulf of Finland, with generally poor conditions for agriculture. Soils and drainage are better, however, on the plateau of the Izhora Upland, which rises from the southern edge of the plain in a steep escarpment, and much of the area has been cleared for agriculture, although mixed forests are scattered throughout the region. The coastal plains and the land north of Leningrad are largely covered with forests of spruce, pine, and birch, where there are many swamps and the soil is generally sandy and podsolic. The whole territory of the oblast has been subject to glaciation, and consequently, morainic deposits and till cover most of

1. A. J. Sjögren, Ubber die Finnische Bevölkerung des St. Peterburgischen Gouvernements und über den Ursprung des Namens Ingermannland (St. Petersburg: Akademie der Wissenschaften, 1833), p. 63.

2. It should be noted that the northern limit of settlement by the Ingrian Finns before 1917 was the boundary between St. Petersburg guberniia in the south and Vyborg guberniia in the north. In 1918, this boundary became the frontier between Finland and Russia. The incorporation of the Finnish part of the Karelian Peninsula into Leningrad oblast at the end of the Second World War did not add to the total Finnish population of the oblast, since all Karelians and Finns living there were evacuated to Finland. The adjustment of the boundary between Estonia and Russia in 1920 led to the incorporation of an area of Estonia with a small Finnish population, known as "Eestin Inkeri" (Estonian Ingria), in what is now Leningrad oblast. 
the area. Because of these conditions, rural settlement is concentrated in the more favorable areas, away from the swamps of the coastal zone and western Ingria and the poor soils and swamps north of Leningrad.

The original inhabitants of Ingria were the Finnic-speaking Vots and Izhortsy. The earliest reference to the Vots appears in the Novgorodian chronicles of 1069.3 Their Russian name is "vod," they call themselves "vaddja," and the Finns refer to them as "vatjalaiset." The Vots probably lived in the area of Ingria between the Luga and Neva rivers since the first century. ${ }^{4}$ The Izhortsy had established themselves in the area of the Izhora River (a southern tributary of the Neva) and, in the thirteenth century, began to move westward into the territory of the Vots. ${ }^{5}$ During the early period of their formation as an ethnic group, they had links with the Finnic peoples of the Karelian Peninsula, as archaeological and linguistic evidence shows. ${ }^{6}$ Although they call themselves "izhoralized," they refer to their language as "karjalan keeli" (Karelian language). The Estonians at one time called them Karelians, but now use the name "isurid." The Russians refer to them as "izhortsy," "izhora," or "ingry," and their Finnish names are "inkerikot" or "inkeroiset." The Germans use the name "Ingrier," sometimes translated into English as "Ingrians." The name "Izhortsy" is preferable, however, because of possible confusion between "Ingrians" and "Ingrian Finns."

The Ingrian Finns made their appearance on the scene at a later date. The Peace of Nöteborg (Orekhov) between the Swedes and the Russians in 1323 resulted in Novgorod's control over Ingria and Swedish domination of the northwestern part of the Karelian Peninsula. The contact between the Izhortsy and the Karelians to the north was thus broken, and there was probably little movement of people into Ingria from the north. By the Peace of Stolbova in 1617, however, the Swedes obtained control of the entire Karelian Peninsula and of Ingria. This event had far-reaching implications for the ethnic composition of the population of the region. Attempts by the Swedes to convert the Orthodox peoples to Lutheranism resulted in the mass exodus not only of Karelians from the north, but also of Vots from Ingria, both groups moving southward into Russian territory. The Karelians formed communities in the Upper Volga region, but the Vots were absorbed by the surrounding Russian-speaking population. ${ }^{8}$ These migrants were replaced by Lutheran Finns who were encouraged by the Swedes to enter and settle the region.

The Finnish migrants came from two areas in Finland: Äyräpää in the central part of the Karelian Peninsula and Savo in southcentral Finland, forming two distinct groups, known as the Äyrämöiset (in Russian Evrimeiset) and the Savakot. Settlement was rapid. In 1620 , only 2 percent of the inhabitants of the district around Iamburg (now Kingisepp) in western Ingria had Finnish

3. A. Laanest, Izhorskie dialekty: Lingvo-geograficheskoe issledovanie (Tallinn: Akademiia Nauk Estonskoi S.S.R., 1966), p. 9.

4. Ibid., p. 8.

5. Ibid., p. 9.

6. Ibid., pp. 8 and 10.

7. S. P. Tolstova et al., Ocherki obshchei etnografi, Evropeiskaia chast' S.S.S.R. (Moscow: Izdatel'stvo "Nauka," 1968), p. 330.

8. Toivo Vuorela, The Finno-Ugric Peoples (Bloomington: Indiana University Publications, 1964), p. 95; Gyula Décsy, Die linguistische Struktur Europas (Wiesbaden, 1973), p. 71. 
names, but by 1695 , the amount rose to 62 percent. By the end of the seventeenth century, the majority of the population of Ingria (72 percent in 1695) had Finnish names. ${ }^{9}$ In 1661 , the main areas of settlement were in the region north of the Neva and in the south and southwest of the region south of the Gulf of Finland. ${ }^{10}$ The Izhortsy and the Vots formed the basic population in the northwestern part of this region, and the other areas were settled by Russians, who had arrived in considerable numbers in the sixteenth century. ${ }^{11}$

By 1702, Russia had wrested control from the Swedes over most of Ingria, a situation which was recognized by the Treaty of Nystad in 1721. Since Finland remained in Swedish hands, the link between the two territories was broken and the movement of Lutheran Finns from the north diminished to a trickle. The annexation of Finland by Russia in 1809, however, resulted in a further influx of Finns.

The first detailed information about the numbers and distribution of the Ingrian Finns appeared in the mid-nineteenth century. The Russian geographer and ethnographer, Peter von Köppen, published an ethnographic map of St. Petersburg guberniia with an accompanying text and statistical tables, which gave a clear picture of the situation around $1848 .{ }^{12}$ The Äyrämöiset, who numbered 29,243 , were living mainly in the coastal region of eastern Ingria, from Strel na in the east to the Gulf of Koper'e in the west, with a smaller group around Tuutari (Dudergof, now Mozhaiskii) to the south, and a larger isolated group to the southeast around Liissilä (Lisino). The Finnish groups north of the Neva were predominantly Äyrämöiset. The Savakot, who numbered 43,080, were concentrated mainly around Saari (Tsarskoe Selo, now Pushkin) and in southern Ingria, from Gatchina in the east to Valkeakirkko (Moloskovitsa) in the west, although many lived in villages along with the Äyrämöiset. ${ }^{13}$ There were also 17,800 Izhortsy and 5,148 Vots, as well as 3,746 new immigrants from Finland, who had settled mainly in the areas north of the Neva along the Finnish border. $^{14}$

Of the two groups, the Äyrämöiset were the oldest, having arrived earlier than the Savakot. The Äyrämöiset and Savakot spoke dialects similar to that of the Viipuri (Vyborg) region, but the Äyrämöiset retained their own national dress and culture longer than the Savakot, who were less conservative. The Savakot originally came from the west, bringing their own costumes, but they had also settled in the Äyräpää district before migrating to Ingria. ${ }^{15}$ The distinction between the two groups is not very important. Another ethnographic

9. Väinö Auer and Eino Jutikkala, Finnlands Lebensraum: Das Geographische und Geschichtliche Finnland (Berlin: Alfred Metzner, 1941), p. 49.

10. Keijo K. Kulha, Inkerin suomalaisten historia (Jyväskylä: K. J. Gummerus, 1969), map on p. 69.

11. Auer and Jutikkala, Finnlands Lebensraum, p. 48; S. S. Gadziatskii, "Bor'ba russkikh liudei Izhorskoi zemli v XVII veke protiv inozemnogo vladychestva," Istoricheskie zapiski, 16 (1945): 14.

12. Peter von Köppen, Erklärender Text zu der Ethnographischen Karte des St. Petersburger Gouvernements (St. Petersburg: Commissionäre der Kaiserlichen Akademie der Wissenschaften, 1867).

13. Ibid., p. 47.

14. Ibid., pp. $47,48,20,41$.

15. Väinö Salminen, "Inkerin suomalaiset," in A. Kannisto et al., Suomen suku (Helsinki: Otava, 1926), pp. 274-75. 
map was produced in 1885 which showed the distribution of the two groups, but in fact there was some confusion about the names. For example, the women's costumes in the Liissilä district were of the Äyrämöiset type, but the dialect was Savakot. By 1927, it was already impossible to distinguish between the two groups, and Köppen's statistical data and map provide the only extant information on their distribution $;^{16}$ by 1962 , the division between the two groups had been forgotten, except in the memory of some of the elderly. ${ }^{17}$ The 1897 Russian census combined the two groups under the heading of "Finns."

The Ingrian Finns managed to retain their individual character, in spite of an increase in the Russian population of the region and the growth of nearby St. Petersburg. The fact that they were Lutherans and had their own churches prevented them from being assimilated into Russian culture at the same rate as the Orthodox Izhortsy and Vots. ${ }^{18}$ Finnish priests taught the children to read and write in their own language. Conditions improved after the abolition of serfdom in 1861. In 1863, a seminary for Finnish teachers was opened in Kolppana. Russian authorities required instruction in Russian for all subjects except language and religion. ${ }^{19}$ Nevertheless, this was an important step in the development of the cultural life of the Finnish population.

Settlers still arrived from the north during the second half of the nineteenth century, especially after the bad crop years of $1866-67$ in Finland. ${ }^{20}$ The number of Finns in Ingria increased from the 72,323 reported by Köppen in 1848 to 130,413 according to the census of 1897 . Because of the accurate records kept in the church books, we have good records of the numbers of Lutheran Finns by parishes since the 1840s. ${ }^{21}$ By 1917, some 127,000 Finns were listed in the church books; of these, some 45,000 lived in the parishes nonth of the Neva, 52,000 in eastern Ingria, and 30,000 in western Ingria. ${ }^{22}$ The discrepancy between the 1897 and the 1917 figures does not represent a drop in the number of Ingrian Finns, but rather a question of definition. Data from the 1897 census

16. D. A. Zolotarev and E. E. Blomkvist, Zapadnye Finny (Leningrad, 1927), p. 5.

17. Z. M. Dubrovina, "Iz istorii finskogo naseleniia Leningradskoi oblasti," Vestnik Leningradskogo Universiteta, no. 20, Seriia istorii, iazyka i literatury, 1962, no. 4, pp. 117-19; Volmari Porkka, Über den Ingrischen Dialekt mit Berücksichtigung der übrigen Finnischingermänlandischen Dialekte (Helsingfors: Frenckell, 1885), map at end of book.

18. Heinrich Laakmann, Ingermanland und die Ingcrmanländischen Finnen (Berlin: Papritz und Kohte, 1942), p. 15. 20.

19. Herman Gummerus, "Finnarna i Ingermanland," Finsk Tidskrift, 111 (July 1931):

20. Sulo Haltsonen, "Inkerin kansan entistä elämää," in Kulha, Inkerin suomalaisten historia, pp. 247-48.

21. For tables of population by parish from 1842 to 1917, see Sulo Haltsonen, "Inkerin suomalaisen kirkon vakiitumisen aikakausi (1800-1917)," in Kulha, Inkerin suomalaisten historia, p. 186.

22. Y. S. Hämeen-Anttila, Inkeri, maantiedettä ja historia (Helsinki: Otava, 1941), p. 69, gives a figure of 126,463; Sulo Haltsonen, Entistä Inkeriä. Inkerin suomalaisasutuksen vaiheita ja kulttuurihistorian piirteitä (Helsinki: Suomalaisen Kirjallisuuden Seura, 1965), p. 63, rounds off Hämeen-Anttila's figures; see also Aappo Metiäinen and Kaarlo Kurko, Entisen Inkerin Luterilaisen Kirkon 350-vuotismuistojulkaisu (Helsinki: Inkere, 1960), passim. From the parish data for 1917 given in the text, a total population of 126,140 is obtained; Juuso Mustonen, Inkerin suomalaiset seurakunnat (Helsinki: Suomalaisen Kirjallisuuden Seura, 1931), p. 20, gives a figure of 130,000; a total of 140,370 Ingrian Finns in 1917 is given by the Ingrian Committee, Ingrian Finns (Helsinki, 1935), p. 15, and later by Laakmann, Ingermanland und die Ingermanländischen Finnen, p. 6, and Kulha, Inkerin suomalaisten historia, p. 359. This figure seems high and is not supported by church book data. 
cover all Finns in St. Petersburg guberniia, including some 21,000 in the city of St. Petersburg, most of whom cannot be regarded as Ingrian Finns. The total rural population of Finnish origin in the guberniia was 107,006. Hence, a figure of some 110,000 Ingrian Finns in 1897 seems reasonable.

The year 1917 marked the beginning of a period of unrest and trouble for the Ingrian Finns. Events surrounding the Revolution and the struggle in 1918 for an independent Finland awakened in the minds of some Ingrian Finns the idea of an independent Ingria. Arms were collected and military training was organized. Many of the young men had already completed military service in the Russian Imperial Army. ${ }^{23}$ A corps of volunteers joined the Estonians in attempts by the White Armies under Generals Rodzianko and Iudenich to clear the Bolsheviks out of Ingria and to take St. Petersburg. Many Estonians also supported the Ingrian independence movement. ${ }^{24}$ With Finnish aid a volunteer corps was also established in northern Ingria. Unfortunately for the Ingrian Finns, the efforts were to no avail. The Russian commanders refused to aid the Ingrians during their occupation of the coastal forts of Krasnaia Gorka and Seraia Loshad', which fell again to the Red Armies. In spite of constant squabbling between the White Russians and the Estonians, a second major offensive was launched against St. Petersburg in October 1919 and the Ingrian forces again attacked Krasnaia Gorka. Even with aid from the British fleet, the assault on the fort failed, mainly because of the lack of Russian cooperation. The entire offensive collapsed and the White Armies were forced to retreat to Estonian territory where they were disarmed.

The Ingrian Finns thus found themselves in a difficult situation. Many who had actively taken part in the struggle against the Reds fled the region and took refuge in Finland or Estonia. Some 8,000 left for Finland with their cattle and property from the parishes in north Ingria along the Finnish border. ${ }^{25}$ (Figure 1 shows the movements of the Ingrian Finns between 1919 and 1945.) There had been an attempted uprising in the region in 1919 in the hope that Finnish armies would intervene. ${ }^{26}$ Refugees in Estonia totaled some $1,000 .{ }^{27}$ However, at the 1920 peace conference at Tartu (Dorpat) between Russia, Finland, and Estonia, the Finnish delegates pressed for a guarantee of the rights of the Ingrian Finns. ${ }^{28}$ The Russians offered general amnesty and the majority of the refugees (about $5,000)$ returned voluntarily to their home territory. In 1926, there were some 2,800 Ingrian Finns left in Finland, a small part of whom were intellectuals who did not wish to return. ${ }^{29}$

According to data from church books, the number of Ingrian Finns had risen to 132,000 by $1919.3^{30}$ From this date on, however, we must rely on information from Soviet sources, which is considerably less than that obtainable for

23. Antti Inkinen, "Die Ingermanländer-Schicksal eines Volkssplitters unter Sowjetrussischer Herrschaft," Osteuropa, 15, no. 10 (October 1965) : 698.

24. Ingrian Committee, Ingrian Finns, p. 3.

25. Antti Tiittanen, Inkeri, Kotikasvatusyhdistyksen Kotiopintokirja, no. 6 (Helsinki, 1922), p. 55 ; Inkeri, 1943 , no. 3, p. 42 ; Kulha, Inkerin suomalaisten historia, p. 359. Figures for refugees range from 7,000 to 8,500 .

26. Ingrian Committee, Ingrian Finns, p. 4.

27. Kulha, Inkerin suomalaisten historia, p. 359.

28. Ingrian Committee, Ingrian Finns, p. 4.

29. Kulha, Inkerin suomalaisten historia, p. 359.

30. Mustonen, Inkerin suomalaiset seurakunnat, p. 23. 


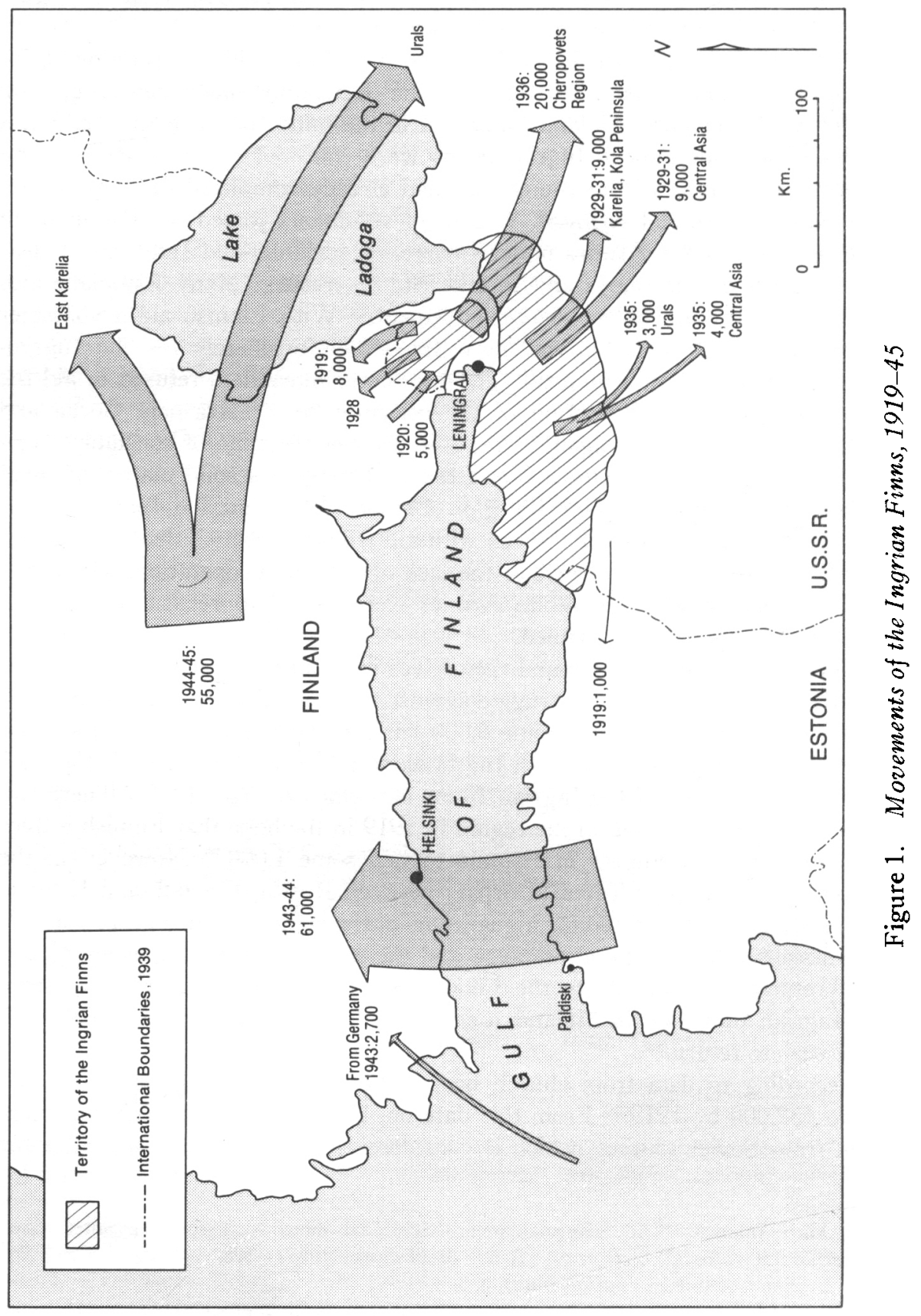


the previous period. Nevertheless, the Soviet census of 1926 gives the most recent detailed information on the numbers and distribution of the population of Ingria. Using this data, along with the information from the church books of 1917 and 1919 and the excellent map by Mustonen showing all the villages in Ingria by ethnic origin of population in 1929, it is possible to produce a map showing the distribution of population in the region in the mid-1920s (see figure 2). ${ }^{31}$ The greatest concentration of Finns was found in the area southwest of St. Petersburg, where the grayish brown carbonized soils of the Izhora Upland provide the best conditions for farming in all of Ingria. The proximity of St. Petersburg as a market for farm products also helps to explain not only the location but also the relative prosperity of the Finnish farmers. Settlement by Finns was also relatively dense in the coastal regions around Peterhof (now Petrodvorets) and Oranienbaum (now Lomonosov), where podsolic soil offered moderately good conditions for agriculture. For the most part, the western areas of the region were avoided by the Finns because of the poor bog soil, although some settlements of Izhortsy and Vots were found on small areas where the soil was podsolic. Near the Estonian border, the Luga River valley, which had alluvial soil, was settled by Finns and Izhortsy. North of St. Petersburg, the Finns had settled on the areas with podsolic soil, avoiding the bog soil found to the east.

The 1926 census of the Soviet Union gives a total of 114,831 "Leningrad Finns" living in Leningrad guberniia. About a hundred others were located in Karelia and about a score in other guberniias. They were thus highly concentrated on their home territory. Some 2,800 lived in Leningrad, but the majority (94 percent) lived in rural areas in their own villages or mixed with Russians. There were 11,053 other Finns in Leningrad guberniia, about 4,000 of whom lived in Leningrad, and 6,400 in rural areas, in many cases with the Ingrian Finns. These Finns were recent arrivals from Finland and were regarded as a separate group. However, the total population of Finnish origin in the guberniia was 125,884 , with approximately 16,000 Izhortsy, 700 Vots, and 66,300 Estonians living mainly in the west and south. Finnish was spoken as first language by 97.7 percent of the Ingrian Finns, indicating the degree to which they had resisted linguistic and cultural assimilation. About 66 percent of Finnish speakers were literate in that language, although over 70 percent of all Ingrian Finns were classed as literate, some obviously able to read Russian rather than Finnish. For a population of peasant small holders at that time their standards of literacy were high. In spite of losses caused by the flight of refugees abroad, the level of population was maintained as a result of a relatively high rate of growth of at least 1 percent per annum..$^{32}$

The 1926 census showed that the Russian population of central Ingria outnumbered the Finnish by a considerable margin. In the rural volosts of Trotskii $u e z d$, where over half of the Ingrian Finns lived, they formed 35.4 percent of the total population; Russians formed 53 percent, Estonians 5 percent, Izhortsy 2.7 percent, and other Finns .9 percent. But in northern Ingria-in the volosts nearest to the Finnish border-the Finns outnumbered the Russians. It is dif-

31. Ibid., map at end of book at a scale of $1: 300,000$. Figure 2 on page 8 is based on Mustonen's map, the Soviet census of 1926, and church book material.

32. Suomalainen Inkeri, Vuosijulkaisu [yearbook], no. 9, 1940-44, p. 9. 


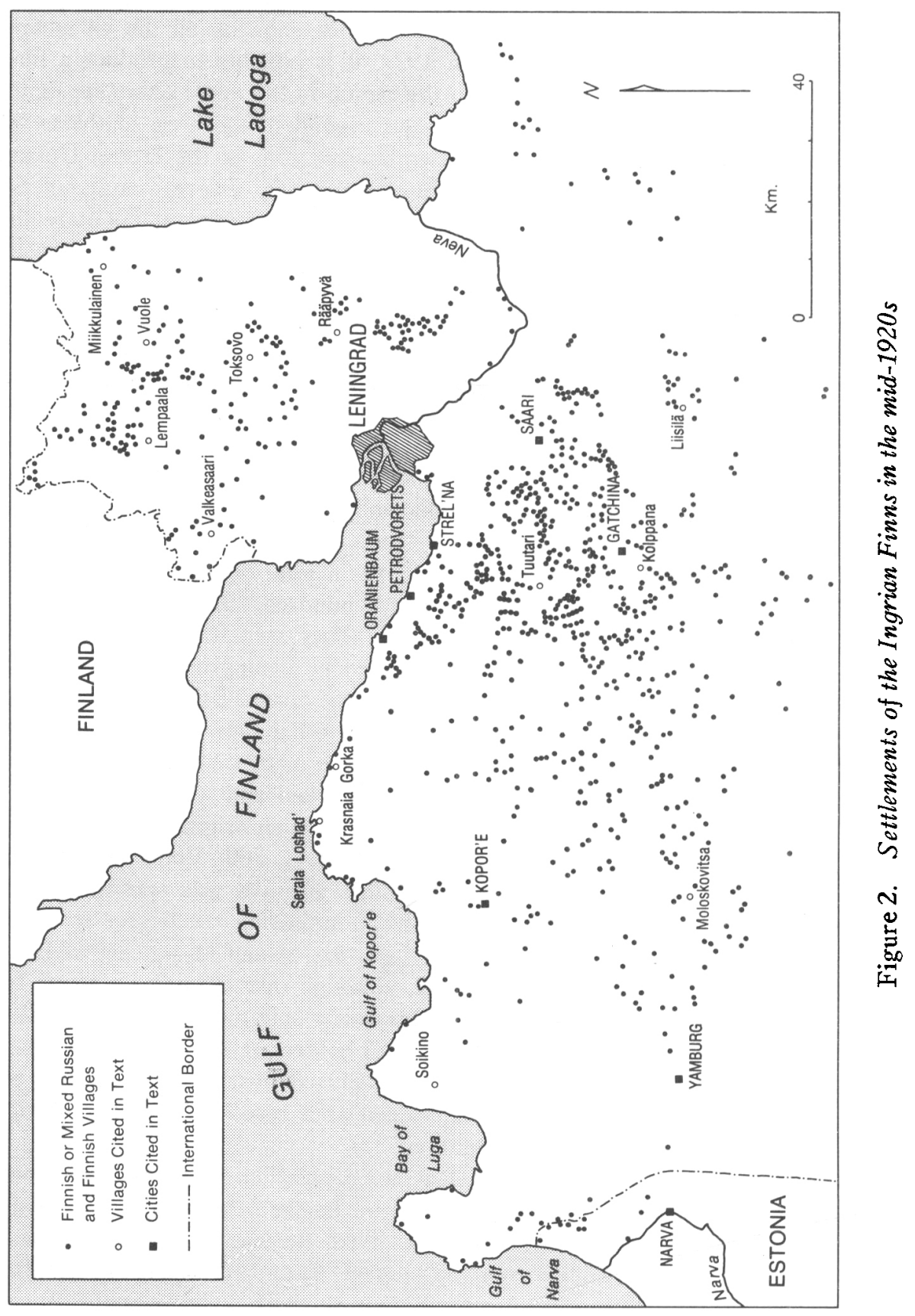


ficult to compare the population statistics obtained from the church books with those of the census because of the difference between parish and volost boundaries, but it is nevertheless possible to note a drop of about 2,500 persons in the population of northern Ingria between 1919 and 1926, which corresponds to the information given above on the number of refugees remaining in Finland.

A short period of concessions by Soviet authorities began in 1928. The Finns in northern Ingria were given a "national district" around Toksovo, where Finnish became the language of education and administration. ${ }^{33}$ However, 1928 was also the year in which the collectivization drive was initiated. The first collective was set up in that year at Rääpyvä (north of Leningrad) by Communist Finns from Canada. ${ }^{34}$ During the 1929-31 period, the first deportations of Finns took place, mainly from northern Ingria to forestry work in Karelia, the apatite mines of the Kola peninsula, and to Central Asia. (Ukrainians, Russians, and Tatars were settled in their place. ${ }^{35}$ ) Some 4,320 families (a total of about 18,000 persons)-presumably the families of rich peasants (kulaks) or others who opposed collectivization or the regime-were moved. ${ }^{\mathbf{3 6}}$ At the same time, some peasants were able to escape to Finland; Soviet sources estimated about 3,000 Ingrian refugees in Finland in 1931,37 and Finnish church books showed 3,206 in 1936.88 The Estonian census of 1934 listed 841 Ingrians in that country. Some of these refugees in both countries had probably left Ingria in 1919, however.

The situation for the Ingrian Finns deteriorated rapidly in the mid-1930s because of the Soviet plan to secure its borders with Finland and Estonia by creating military zones from which all non-Russians would be expelled, on the grounds that they were politically unreliable. In April 1935, 2,000 familiesabout 7,000 persons-were deported, with 4,000 Ingrian Finns going to Central Asia and 3,000 to the Ural region. ${ }^{39}$ In May and June 1936, about 20,000 persons were expelled from the border parishes of Valkeassari, Lempaala, Vuole, and Miikkulainen in northern Ingria, and were resettled among the Russian population in poor collective farms around Cherepovets in the eastern part of Leningrad oblast. ${ }^{40}$ Their parishes were completely emptied of their Finnish-speaking population and were settled with Russians. The Finnish national district was abolished

33. Nikolai K. Dekker and Andrei Lebed, Genocide in the U.S.S.R. (Munich: Institute for the Study of the U.S.S.R., 1958), p. 56.

34. Kulha, Inkerin suomalaisten historia, p. 361.

35. Laakmann, Ingermanland und die Ingermanländischen Finnen, pp. 19-20.

36. Ingrian Committee, Ingrian Finns, p. 12; Kulha, Inkerin suomalaisten historia, p. 359; Hämeen-Anttila, Inkeri, maantiedettä ja historia, p. 97.

37. I. M. Lemetti, Sovetskaia Ingermanlandiia (Moscow-Leningrad: Gosudarstvennoe sotsial'no-ekonomicheskoe izdatel'stvo, 1931), p. 53.

38. Keijo K. Kulha, "Inkeriläisten siirtäminen Suomeen II maailmansodan aikana," Historica II, Studia Historica Jyväskyläensia, vol. 5 (Jyväskylä, 1967), p. 224; Kuusaari gives 4,500 Ingrian refugees in Finland (see Eero Kuusaari, Suomen suvuntiet [Helsinki: Suomen Heimosoturien Liitto, 1935], p. 221).

39. Ingrian Committee, Ingrian Finns, p. 14. These figures are quoted in several other sources.

40. Juuso Mustonen, "Nykypäivien Inkeri," Suomalainen Inkeri, no. 6, 1937, p. 40; Y. S. Hämeen-Anttila, Inkeri, maantiedettä ja historia, p. 104; Kulha, Inkerin suomalaisten historia, p. 359. 
the following year, Lutheran churches were closed and many of the priests deported along with their parishioners. ${ }^{41}$

The figure for the 1936 deportations of the entire Finnish population from the four northern parishes agrees with the population for these parishes in 1919, which totaled about 19,500 , and in 1926 , when the population of approximately the same area was about 18,900. Total deportations from 1928 through 1936 are given as 40,000 or $50,000.42$ The total figure of 45,000 persons corresponds with the sum of the figures given separately for the various deportation periods.

It is difficult to estimate the number of Finns remaining in Ingria at the beginning of the Second World War, since the Soviet census of 1939 gives no details about the location of the Finnish-speaking population of the country. A total population of 143,074 Finns was given for the Soviet Union. Judging by data for 1935, about 13,000 of these probably lived in the Karelian ASSR. ${ }^{43}$ Because of deportations and other movements, however, the remaining 130,000 Finns would not all be located in Leningrad oblast. Deducting the figure of 45,000 to allow for those Finns living outside of Ingria gives a figure of some 85,000 still living in their home territory. ${ }^{44}$

The advent of World War II marked another decisive stage in the fortunes of the Ingrian Finns. In particular, the siege of Leningrad and other military campaigns fought on the territory of the Ingrian Finns resulted in its division into areas of German and Soviet control, a situation which lasted virtually unchanged from 1941 until 1944. The line to the west and south of Leningrad cut through the extreme eastern edge of the Finnish area of settlement; consequently, few of the rural Finnish inhabitants of western Ingria were isolated when Leningrad was besieged. All of northern Ingria remained under Soviet control, however. The Finnish army had refused to advance beyond the 1939 Soviet-Finnish border after regaining the territories lost in the Winter War of 1939-40. In addition, a sector of the coastal area of central Ingria between Peterhof and the Gulf of Kopor'e-probably containing around 2,000 Finns and 4,000 Izhortsy ${ }^{45}$ - was held by the Soviet army for the entire period of the war. The main division thus lay between the Finns of central and western Ingria, who found themselves in German-occupied territory, and those in northern Ingria, who were still under Russian control. Taking into account the deportations of the 1930s, the total Finnish population remaining in the Russian-controlled territory of northern Ingermanland must have been about 20,$000 ; 4^{46}$ those in the

41. Dekker and Lebed, Genocide in the U.S.S.R., p. 56; Ingrian Committee, Ingrian Finns, p. 13; Mustonen, "Nykypäivien Inkeri," p. 38.

42. Mustonen, "Nykypäivien Inkeri," p. 40; Kulha, Inkerin suomalaisten historia, p. 359; Keijo K. Kulha gives another figure-40,000-for the 1928-38 period (see Kulha, "Inkeriläisten siirtäminen suomeen II maailmansodan aikana," p. 226).

43. "Karel'skaia A.S.S.R.," Bol'shaia sovetskaia entsiklopediia, vol. 31 (Moscow, 1937), p. 513 (hereafter cited as $B S E$ ).

44. Antti Inkinen gives a figure of "scarcely more than 75,000" Ingrian Finns in 1941, based on their own estimates which he obtained during the German occupation, but it is not clear if this figure applied to the whole region or only the German-controlled area (Inkinen, Ingermanland und die Ingermanländischen Finnen, p. 697).

45. These estimates are based on the 1926 census figures and Mustonen's map.

46. Calculations based on data from the church books for 1917 and 1919 suggest a figure of some 20,000 . 
German-controlled area must have amounted to some $65,000 .{ }^{47}$ A recent Finnish study quotes the same figure, but gives the number of Ingrian Finns in Sovietcontrolled territory as 30,000 , although expulsions and deaths make this a difficult figure to estimate. ${ }^{48}$

In 1941, the German occupation authorities began discussions with the Finnish government about the possibility of evacuating the Ingrian Finns to Finland. Because the details of these discussions and subsequent events have been fully covered elsewhere, this study will only consider the numbers of persons involved. ${ }^{49}$ In December 1941, the Germans suggested that the Finns move 50,000 Ingrians over the frozen Gulf of Finland, but the Finns declined on the grounds of lack of transport and food. ${ }^{50}$ The first evacuation did not take place until 1943. (In the meantime, however, some Ingrian Finns had been moved to Estonia, raising the number there to about 18,000, and approximately 3,000 Ingrian Finns had moved voluntarily to Germany, settling mainly around Danzig, Breslau, and Glogau. ${ }^{51}$ ) The first group of Ingrians to be evacuated left the port of Paldiski in Estonia in March 1943 and by mid-November 22,050 had arrived in Finland. In the five-month period between November 1943 and April 1944, an additional 38,283 Ingrian Finns landed at the Finnish ports of Hanko and Turku. A total of 61,163 Ingrian Finns (including 357 Estonian Finns) came to Finland via Paldiski.52 Another 2,700 Ingrians who had worked in Germany also arrived in Finland in July 1943. ${ }^{53}$ Finnish records show that at the end of November 1944 there were 63,211 Ingrian Finns settled in the country, mainly in the south. ${ }^{54}$ Although the Germans had originally suggested the move in order to add to the Finnish labor force, whole families-mostly farmers with few industrial workers-were in fact resettled..$^{\mathbf{5 5}}$

This mass movement of Ingrians probably left about 2,000 on their home territory or in Estonia. It is impossible to determine how many of these or of the other Ingrian Finns living behind the Russian lines were still alive by the end of the war, since central and western Ingria were the scenes of heavy fighting in 1944. At any rate, by the end of the war, many of the villages and towns of the region had been destroyed or heavily damaged.

47. If we assume the figure of some 85,000 Finns living in Leningrad oblast in 1939 and then subtract the numbers on Soviet-controlled territory $(20,000$ in northern Ingermanland and 2,000 in western Ingermanland) we arrive at a figure of some 63,000 Finns on Germancontrolled territory. Keijo K. Kulha gives a figure of 65,000 , which seems reasonable (Kulha, Inkerin suomalaisten historia, p. 379). It should be emphasized that the above figures are too vague to be reliable as a basis for calculations.

48. Ibid., pp. 378 and 379. The figure of 30,000 Finns behind the Russian lines was also given by Pentti Kaitera, "Tärkeitä tietoja inkeriläisille," Inkeri, 1943, no. 19, p. 283. The figure of 78,000 Finns in the German-controlled region was given in Itä-Karjala, no. 13 (July 19, 1944), p. 2. This figure seems high.

49. The history of the evacuations is given in Kulha, Inkerin suomalaisten historia, pp. 377-404 and in Kulha, "Inkeriläisten siirtäminen Suomeen II maailmansodan aikana," pp. 224-60. Photographs of the evacuation are contained in Antti Hämäläinen, Kadonnutta Inkeriä (Porvoo-Helsinki: Werner Söderström, 1944), no pagination, last section of book.

50. Kulha, "Inkeriläisten siirtäminen Suomeen II maailmansodan aikana," p. 232.

51. Ibid., pp. 237 and 243.

52. Kulha, Inkerin suomalaisten historia, pp. 390 and 392 ; Kulha, "Inkeriläisten siirtäminen Suomeen II maailmansodan aikana," p. 260.

53. Kulha, Inkerin suomalaisten historia, p. 393.

54. Kulha, "Inkeriläisten siirtäminen Suomeen II maailmansodan aikana," p. 255.

55. "Inkeriläiset Suomessa," Swomalainen Inkeri, 1940-44, p. 4. 
Unfortunately for the Ingrians, their movement to Finland was not a final solution to their problems. In September 1944, the Finnish government signed an armistice agreement with the Russians, effectively ending the armed conflict between them. Apart from the articles of the agreement which involved the transfer of Finnish territory to the Soviet Union, one article specifically dealt with the question of the Ingrian Finns. The Soviet authorities demanded the compulsory return only of certain categories of orphans and unsupported children as well as the return of 729 men who had fought in the Ingrian battalion that had formed part of the German forces. Persons who had been moved from Soviet territory against their will were given the right to return. The return of the mass of the Ingrians was not demanded, and no legal reason for them to leave Finland was given. In spite of this, some 55,000 Ingrian Finns returned to the Soviet Union between the beginning of December 1944 and mid-January $1945 .^{56}$ In October 1944, when Finnish authorities approached the Ingrian community about their attitude toward the treaty provisions, some of them announced their intention of returning to the Soviet Union. ${ }^{57}$ It is possible that the Finnish repatriation authorities incorrectly explained the provisions of the agreement to the Ingrians, but it is probable that the Ingrians feared forced repatriation if they did not return voluntarily. They were deeply attached to their families, a factor which could influence an individual to leave along with his relatives. ${ }^{58}$

No exact information is available about the fate of the Ingrian Finns after 1945. Approximately 8,000 stayed in Finland, and of these, about half later moved to Sweden for greater security, settling mainly in the Göteborg area. ${ }^{59}$ In most cases, those who remained in Finland concealed their origin, thus making it difficult to assess their numbers. Of those who returned to the Soviet Union, only a few seem to have been resettled in their homeland and most were taken either to the interior of the country-especially to the Ural region-or to East Karelia, ${ }^{60}$ where a village of Ingrians is located near Petrozavodsk. ${ }^{61}$ A Soviet source states that part of the Finnish-speaking population that was evacuated to the interior of the country remained there after the war. Many were killed, and others were evacuated to German-controlled territory and to Finland. The reduction in numbers of the Finnish population in Leningrad oblast is also explained by the fact that part of them were moved to the Karelian ASSR. ${ }^{62}$

The only demographic information available for the postwar period comes from the Soviet censuses of 1959 and 1970. The data are summarized in table 1. Unfortunately, there is no distinction made in the censuses between Ingrians and other Finns. However, a comparison of the latest figures with those from earlier

56. Kulha, Inkerin suomalaisten historia, p. 402.

57. "Paluu Neuvostoliittoon," Inkeri, 1944, no. 19, p. 284.

58. Kulha discusses this problem. Discussions with Finns on this subject suggest that fear of eventual compulsory repatriation was the strongest factor affecting the Ingrians' decision. They wished to avoid the stigma of being unwilling repatriates. That the Finnish authorities were worried about harboring ex-Soviet citizens is seen in the attempts in 1949-50 to uncover and repatriate the remaining Ingrians in Finland, a relatively unsuccessful operation (see Kulha, Inkerin suomalaisten historia, pp. 402-3).

59. Ibid., p. 402.

60. Ibid.

61. A Finnish informant had visited this village, no doubt one of several in the region.

62. V. N. Belitser et al., Narody Europeiskoi chasti S.S.S.R., vol. 2 (Moscow: Izdatel'stvo “Nauka," 1964), p. 314. 
Table 1. Finns in the Soviet Union by Administrative Region

\begin{tabular}{lrr}
\hline & 1959 & 1970 \\
\hline Total in Soviet Union & 92,717 & 84,750 \\
RSFSR & 72,356 & 62,307 \\
Total in Leningrad oblast: & 20,043 & 19,897 \\
rural population & 17,605 & 15,793 \\
urban population & 2,438 & 4,104 \\
Leningrad city & 3,150 & 4,376 \\
Total in Karelian ASSR: & 27,829 & 22,174 \\
rural population & 7,865 & 4,539 \\
urban population & 19,964 & 17,635 \\
Total in Estonian SSR: & 16,699 & 18,537 \\
rural population & 8,116 & 7,455 \\
urban population & 8,583 & 11,082 \\
\hline
\end{tabular}

Sources: 1959: Tsentral'noe statisticheskoe upravlenie, Itogi vsesoiuznoi perepisi naseleniia 1959 goda RSFSR (Moscow, 1963). 1970: TsSU, Itogi vsesoiuznoi perepisi naseleniia 1970 goda, vol. 4 (Moscow, 1973).

periods leads to certain conclusions. Assuming that about 22,000 Ingrian Finns were living in the rural areas of Leningrad oblast under Soviet control during the war, and that there were probably some 2,000 left on German-controlled territory-including Estonia-after their evacuation to Finland, the return of 55,000 persons from Finland would result in a total population of Ingrian Finns in the Soviet Union of at least 79,000. A more accurate estimate cannot be made because of the lack of information on the fate of the 45,000 persons who were deported in the 1930s. Similarly, there are no data on the numbers killed during the war or on the rate of natural increase of the population. Deportations and movements before, during, and after the war have made the exact location of this population impossible to determine. The difference between the figure of 79,000 and the 1959 census total of all Finns in the Soviet Union of 92,717 (about 13,700) can be accounted for by including the survivors of the deportations of the $1930 \mathrm{~s}$, by the natural rate of population growth, or by an undetermined number of Finns who were not Ingrians. ${ }^{63}$ The question of the rate of increase is a difficult problem to solve. Comparison of the 1959 and 1970 figures shows a decrease of some 8,000 persons and it is difficult to say when this trend began. Consequently, bridging the statistical gap between the prewar period and the 1950 s is virtually impossible.

A study of the 1959 figures reveals a few points of interest. Of the 92,717 Finns in the Soviet Union, only about 20,000 lived in Leningrad oblast. It can be assumed that most of these persons represented the remnants of the old Ingrian population still left on their original territory. There were 3,150 Finns living in the city of Leningrad, and their origin is impossible to determine. Of the 69,500 Finns living outside of Leningrad oblast and city, approximately 28,000 were located in the Karelian ASSR. In 1935, some 13,000 Finns lived in Karelia, ${ }^{64}$ but again it is impossible to estimate how much of the increase during a period

63. In 1926, there were some 16,000 Finns who were not of Ingrian origin. It is, however, impossible to apply this figure after the passage of forty years.

64. "Karel'skaia A.S.S.R.," BSE, vol. 31, p. 513. 
of twenty-five years is attributable to natural increase or movements of population, especially of Ingrians, into the region. The 16,700 Finns recorded in the Estonian SSR constitute a significant increase over the 1,088 Finns and 841 Ingrians shown in the 1934 census. As noted above, some 18,000 Ingrian Finns had been moved to Estonia before the large-scale evacuations to Finland in 1943 ; the 1959 figures therefore probably include a large proportion of Ingrians. About 24 percent of these Finns gave Estonian as their first language, indicating a fairly lengthy period of settlement as well as assimilation to Estonian culture. Of the remaining 25,000 Finns, 21,000 were located somewhere in the territory of the RSFSR, outside of their traditional homeland or Karelia, and another 4,000 lived elsewhere in the Soviet Union. These 25,000 Finns were the remnants of the prewar deportations, of wartime evacuation, and perhaps of resettlement of the Ingrians who returned from Finland.

Thus, of the postwar Finnish population of the Soviet Union, few could be identified as inhabiting their original territory. Most of the 20,000 living in Leningrad oblast were still in rural areas, probably in some of their original villages. A Soviet study published in 1962 claimed that the Finns of Leningrad oblast lived predominantly in the same places where they had previously lived. ${ }^{65}$ A map published in Estonia in 1964 shows several villages along the coast where the inhabitants still speak Finnish, Izhorian, and Vottish. ${ }^{66}$ Unfortunately, because the map is intended to illustrate the present distribution of villages where Izhorian is spoken, it does not cover all the areas of Leningrad oblast where presumably some Finnish-speakers still live. However, a comparison of the number of villages where Finnish is still spoken-in the area extending along the coast from Leningrad westward to the Gulf of Narva-with those shown on Mustonen's prewar map indicates that Finnish and Izhorian are no longer spoken in the villages located in the coastal zone from Leningrad to Lomonosov (formerly Oranienbaum) and beyond (see figure 2). This was an area that experienced heavy fighting during the war, and was shown on U.S. postwar maps to have many destroyed and partially destroyed villages. ${ }^{67}$ The villages in the area on the east coast of the Gulf of Kopor'e-which were some distance from the front line, located in Russian-held territory, and relatively isolated from the south by an area of swamps-seem to have retained at least some of their original Finnish and Izhorian population. To the west, the Izhorian language is still spoken in a few villages around the Bay of Luga, and Finnish is spoken in three villages on the Gulf of Narva. Before the war, this was a rather sparsely inhabited region with much swampy terrain. It seems, however, that many of the Izhorian villages on the Soikino peninsula and Finnish villages along the Gulf of Narva have vanished or have been settled by Russians. Soviet ethnic maps published after the war give little detailed information on the location of the Ingrian Finns. Two maps published in the 1960s show a mixed Finnish and Russian population living in the area of southern Ingria between Gatchina and Kopor'e, an area where the

65. Dubrovina, "Iz istorii finskogo naseleniia Leningradskoi oblasti," p. 119.

66. A. Laanest, Isurdi ja isuri keel (Tallinn: Eesti N.S.V. Teaduste Akadeemia Keele ja Kirjanduse Instituut, 1964), map opposite p. 5.

67. U.S. Army Map Service, Eastern Europe, series N 501, 1:250,000, sheet NO35-3. Information on this sheet was compiled from 1936-44 topographic maps and 1943-44 air photography. 
Finnish population was concentrated before the war. ${ }^{68} \mathrm{~A}$ recent Soviet map shows some Finns also living in the area of northern Ingria, immediately north of Leningrad. ${ }^{69}$ The scales of these maps are too small, however, to show locations with any accuracy.

The figures from the 1970 census reveal a decrease in the total Finnish population of the Soviet Union to 84,750 , or some 8,000 less than in 1959. The number of Finns in Leningrad oblast remained about the same $(19,897)$ and the number living in the city of Leningrad actually rose by over 1,000 . The number of Finns in the Estonian SSR also rose to 18,537 , an increase of some 1,800. These figures suggest that the remnants of the Ingrian Finns in Leningrad oblast were barely maintaining their numbers, while those in Estonia were actually increasing at a rate of about 1 percent per annum. The decline is most notable in the Karelian ASSR, where a total of 22,174 Finns was recorded, a decrease of some 5,700 persons. Similarly, the number of Finns living in other areas of the RSFSR decreased by about 5,100 .

The maintenance of the numbers of Finns living in Leningrad oblast and the decrease in those living in the Karelian ASSR may be related. In the mid1960s, a number of Ingrian Finns were permitted to return to their homeland from other parts of the Soviet Union, apparently with the hope that they would be able to improve agricultural production in the region, which had not flourished because of the incompetence of the Russian peasants and of other peasants of Slavic origin who had settled in the region. There were said to be some problems associated with resettling the Finns in villages now inhabited by the more recent settlers. ${ }^{70}$ No official Soviet version of this story has been made public, but the population data suggest that there has been a movement of Finns from the Karelian ASSR and other regions of the Soviet Union to Leningrad oblast and possibly to Estonia.

The decrease in the total number of Finns is almost certainly attributable to the increasingly rapid rate of assimilation to Russian language and culture during the period following the war. In 1959, only 59.5 percent of all Finns in the Soviet-Union used Finnish as their first language, and by 1970 this figure had dropped to 51 percent. In Leningrad oblast, the percentage of Finns speaking their native language as first language dropped from 66.6 to 58.4 , compared to a figure of 97.7 percent in 1926. Finns living in the rural areas of the oblast in 1970 managed to retain their language better than those in the urban areas, with 65.2 percent of them speaking Finnish as their first language. Of the Finns living in the city of Leningrad, only 27.7 percent maintained their language. The data given in table 1 reveal a considerable rate of urbanization among the Finnish population of the Karelian ASSR and the Estonian SSR in particular, and this partially accounts for the decline of Finnish speakers in those republics. Moreover, assimilation to Estonian language and culture is also noticeable among the Finns living in that republic. Of the 18,537 living in the Estonian SSR in 1970, some 27.8 percent spoke Estonian as their first language, 20.4 percent spoke Russian, and only 51.8 percent spoke Finnish.

68. S. P. Tolstova et al., Ocherki obshchei etnografii, map opposite p. 464; V. N. Belitser et al., Narody Evropeiskoi chasti S.S.S.R., map facing p. 336.

69. V. I. Lytkin et al., Osnovy finno-ugorskogo iazykoznaniia: Pribaltiisko-finskie, saamskii i mordozskii iazyki (Moscow: Izdatel'stvo "Nauka," 1975), p. 7.

70. Inkinen, "Die Ingermanländer," p. 695. 
It can be argued, of course, that the shift to the use of Russian or Estonian does not mean complete Russification and is only a stage along the path to total assimilation. ${ }^{71}$ However, it is obvious that the rapid loss of language means that the process leading to eventual identification as a Russian or Estonian is taking place among a substantial number of Finns and that, if this trend continues, the total number of Finns recorded in the next Soviet census will show, at the least, a decrease to below 80,000 , with less than 50 percent using their language as first language.

The Ingrian Finns were the victims of an unfortunate geographical location. Their adherence to their religion, language, and culture was not the basic reason for their suffering, but rather the fact that they were located in the area surrounding the city of Leningrad. The proximity of Leningrad to the Finnish and Estonian borders led Stalin to attempt to expand the Soviet borders in these areas by the eventual annexation of the Karelian isthmus and Estonia on the eve of the Second World War. The removal of the Ingrian Finns from the sensitive areas was part of this larger plan. The siege of Leningrad and the other events of the war in the region completed the process which the deportations of the 1930s had begun, namely, the virtual disappearance of the Ingrian Finns as a distinct ethnic group. Although there are probably some 15,000 Ingrians still living in or near the original villages in their homeland and retaining the Finnish language more effectively than any other group of Finns in the Soviet Union, they are the last remnants of a people who not so long ago gave the rural areas of Ingria their distinctive Finnish air.

71. The subject of assimilation of ethnic groups in the Soviet Union, as revealed by available statistical data, is discussed by Robert A. Lewis, Richard H. Rowland, and Ralph S. Clem, Nationality and Population Change in Russia and the U.S.S.R.: An Evaluation of Census Data, 1897-1970 (New York: Praeger, 1976), pp. 282-87. The population movements of the Ingrian Finns make it impossible to use the historical comparison of population data to determine rates of assimilation, as suggested by the authors. 